\title{
THE KEY SUCCESS AND STRATEGIC ROLE OF ACCRUAL BASED ACCOUNTING IMPLEMENTATION
}

\author{
Surepno \\ Universitas Diponegoro \\ Jl. Prof. H. Soedarto, SH, Tembalang, Kota Semarang \\ repnofine@gmail.com
}

\begin{abstract}
Central Government policy to adopt accrual-based accounting system providing consequences for local governments to apply accrual accounting in the financial statements. Empirical evidence shows that the readiness of the local government in Indonesia in the process of implementation of accrual accounting is still relatively low. This study aimed to analyze the success of Semarang Government in implementing accrual accounting. This study also analyzes the offender's response to the implementation of the strategic role of accrual accounting in transparency and accountability. Furthermore, the method used in this study is a qualitative approach to perform a case study at the Department of Finance and Asset Management Area (DPKAD) Semarang by means of interviewing the key actors of implementation. The results showed that the successful implementation of accrual accounting Semarang government is supported by four main strategies, namely management commitment, regulatory development, information systems development and human resource development. Furthermore, based on the conclusions of the implementers shows that accrual accounting has a strategic role in increasing transparency and accountability through financial reporting.
\end{abstract}

Keywords: key success, starategic role, implementation, accrual basis

\begin{abstract}
ABSTRAK
Kebijakan Pemerintah Pusat untuk mengadopsi sistem akuntansi berbasis akrual memberikan konsekuensi bagi pemerintah daerah untuk menerapkan akuntansi berbasis akrual dalam penyusunan laporan keuangan. Bukti empiris memperlihatkan bahwa kesiapan pemerintah daerah di Indonesia dalam proses implementasi akuntansi berbasis akrual masih relatif rendah. Penelitian ini bertujuan untuk menganalisis kesuksesan Pemerintah Kota Semarang dalam implementasi akuntansi berbasis akrual. Penelitian ini juga menganalisis respon pelaku implementasi terhadap peran strategis akuntansi berbasis akrual dalam transparansi dan akuntabilitas. Selanjutnya metode penelitian yang digunakan adalah pendekatan kualitatif dengan melalukan studi kasus pada Dinas Pengelolaan Keuangan dan Aset Daerah (DPKAD) Kota Semarang dengan cara mewancarai aktor kunci impelementasi.Hasil penelitian menunjukkan, keberhasilan implementasi akuntansi berbasis akrual Pemerintah Kota Semarang didukung oleh empat strategi utama yaitu komitmen pimpinan, pengembangan regulasi, pengembangan sistem informasi dan pengembangan sumber daya manusia. Selanjutnya berdasarkan kesimpulan para pelaku implementasi menunjukkan akuntansi berbasis akrual memiliki peran strategis dalam peningkatan transparansi dan akuntabilitas melalui pelaporan keuangan.
\end{abstract}

Kata kunci: kunci sukses, peran strategis, implementasi, akuntansi berbasis akrual 


\section{INTRODUCTION}

In 2015, all local governments in Indonesia must use accrual based accounting standards. This makes local government to have no other choice to postpone the implementation of the accrual-based accounting standards. Government Regulation (PP) No. 71 Year 2010 becomes the basis for preparing the financial statements of local governments. This regulation is enhanced with Home Affairs Minister Regulation No. 64 Year 2013, which set the technical making of local government financial statements on an accrual basis.

The purpose of government in implementing accrual based accounting standards is certainly to improve the quality of financial information from the local government. One of the improvements is in terms of transparency and accountability of local government financial reports. However, the implementation of this accrual based standard needs quality and commitment from the local government to be able to implement it properly. This problem still becomes an issue since the human resources are not owned as expected. Thus, the implementation of accrual based accounting standards is considered too forced.

The demand for public information has been entrusted by Act (UU) No. 14 of 2008 pertaining public disclosure. The emergence of that Act makes local government as public entity have responsibility to provide information which is owned by the public at large. Information that must be published is Local Government Financial Reports (LKPD). Information disclosure will become a system that can prevent corruption, collusion, and nepotism (KKN).

Public information that should be conveyed by local government is local government financial report. Financial report has become accountability tool for the use of public funds by the local government. Even though in the implementation of accrual based accounting is more complicated compare to cash basis accounting, however the government remains on the option of using accrualbased accounting standards. Although the cash-based accounting has long been used in the record, there are still many local governments that are getting a reasonable opinion with exception as well as unreasonable opinion.

Problems arise due to concerns of local governments are not able to meet the expectations of the central government to present accrual-based financial statements. This concern is very reasonable since most local governments do not have resources that can support the implementation of accrual based accounting. Primarily, local governments still have constraints on human resources which are experts at government accounting. Khan and Meyes (2009) stated that in order to succeed in implementing accrual based accounting, there are four conditions that should be prepared, such as: accounting system readiness, leader policy, technical skill and system.

Setyaningsih (2013) found that one of the reasons local government is not ready towards the implementation of accrual based accounting system is there is still no firm commitment from the head of the region to implement it. Exploration study that was conducted by Setyaningsih related to the level of understanding of government officials and board members in Solo showed that the level of understanding of local government officials toward the accrual based accounting standard was still low. Difficulties faced within the implementation, among others are, minimum facilities, inappropriate educational staff, inexperience, lack of socialization and lack of incentives for good SAP implementation.

Tarigan (2012) conducted a study on whether accrual based accounting adoption policies can improve the transparency and accountability in the Department of Regional Tax and Financial Management (DPDPK) of Yogyakarta. The result showed that local government officials in DPDPK 
of Yogyakarta consider that the accrual-based accounting system was capable of improving the transparency and accountability of financial reports. Thus this research has the purpose to further analyze the success of Semarang Government in the implementation of accrual based accounting as well as to analyze the response of implementers towards the strategic role of accrual based accounting in transparency and accountability.

Related with the keys to the success of the implementation and strategic role of accrual based accounting, this study is based on empirical evidence found by Baboojee (2011) and Rkein (2008) relating to the benefits of the application of accrual based accounting. Baboojee (2011) formulated the problems related on whether the implementation of accrual based accounting was important in service enhancement. Result showed that there was no influence from accrual based accounting towards service enhancement. However, different result found by Rkein (2008) who conducted related research with accrual accounting and public sector reformation in Australia. Rkein (2008) showed that the implementation of accrual based accounting in Australia was in conjunction with the reformation policy in public sector. Adoption carried out gradually where adoption initially made in business like services before applied to all parts of the public sector. Rkein's research showed that accrual accounting provided strategic benefits, although incomplete and varied in each instance.

Semarang which succeeds the application of accrual accounting earlier, provides a pretty good response. Thus, further disclosure of Semarang Government regarding the process of implementation of accrual based accounting is required. This study will focus on the implementation of accrual-based SAP in the Department of Finance and Asset Management Area (DPAKD) Semarang because, apart from being a SKPD and SKPKD (Unit Regional Finance Management), DPKAD Semarang is a work unit of Semarang Government which implements and responsible for the implementation of accounting and financial reporting systems in Semarang Government.

\section{Institutionalization Process Model (IPM)}

Semarang government as the earliest government in adopting accrual based accounting make Semarang as a role model of the success of accrual based accounting implementation. Success could not be separated from Semarang Government to make a change with accounting system from cash basis into the accrual basis although, on occasion, there have been no official regulations that govern them.

Hence, the concept of IPM from Dambrin, Lambert, and Sponem (2007) serves as a theoretical basis for analyzing the process of implementation of accrual based accounting in Semarang Government in its efforts to implement accrual based accounting. According to Dambrin, Lambert, and Sponem (2007), the process of institutionalization is a new system which passes through four stages: (1) deployment of new ideals, (2) creation a new goal in the development of policies (new procedure), (3) development of specific management tools based on new ideals, (4) the implementation of certain techniques (internalization). Dambrin, Lambert, and Sponem (2007) found that the institutionalization process of Monitoring Management System in a pharmaceutical company was conducted by a manager as a means to increase efficiency. However, they also found the difficulty in the new system which is going to be internalized.

\section{Implementation of Accrual Based Accounting}

The implementation of accrual basis in the accounting system of government within a country is not an easy task. ADB (Asian Development Bank) particularly highlights the problem of implementation of the accrual basis for developing countries as outlined in a paper entitled Accrual Budgeting and Accounting in Government and its Relevance for Developing Member Countries and provide seven recommendations for the implementation of the accrual basis of developing countries. 
First, prudence in choosing the strategy of accrual basis implementation. There are two main models in implementing the accrual basis namely big bang models and phased models. Advantages of the big bang approach are conducive to a change of organizational culture, rapidly achieve the goal, and can avoid the risks of interest. Meanwhile, the advantages of profits phased approach are the problems that may arise can be noticed along with the solution during the transition period, the cash basis can still be done in parallel to reduce the risk of failure.

Second, political commitment is one of the important keys. The political commitment in implementing the accrual basis for developing countries becomes very essential, so that political commitment is necessary to eliminate any incompatible interests. Third, the aim should be eliminated. The results and the benefits to be achieved with the implementation of an intense accrual basis should be communicated to the parties concerned.

Fourth, the need for reliable power accountants. Professional accountants would be necessary for sufficient recruiting and training. Accountant shortage will cause delays in the implementation of the accrual basis of government accounting. Fifth, accounting information system should be sufficient. Cash-based accounting information is an important point in turnover from basis to accrual. If a country has not had a reliable cash-based accounting system, then the country must first concentrate on improving systems and processes that already exist, before considering the shift to accrual accounting basis.

Sixth, the highest audit agency must have the right resources. The audit agency holds a very important key in implementing accrual basis. It takes several years to conduct audit professionalism. Seventh, implementation of accrual basis should be a part from bureaucratic reform. Implementation of accrual basis should not only be seen as a matter of accounting techniques, but this implementation requires organization cultural change and must be a part from the bureaucracy reform as a whole.

\section{METHOD}

This study uses an interpretive approach due to: (1) understanding emerged through interaction; (2) understand the context; (3) how to understand the experience of informants; (4) how the informants create and share understanding. In addition Interpretive allow researchers to engage subjectively by the study participants. Interpretive researchers believe that the reality in form through the interpretation and social interaction (Hines, 1998; Miller, 1994; Morgan, 1998; Munro, 1998 in Chariri, 2006). This is consistent with the purpose of the research namely to understand the process of implementation of accrual accounting and strategic role in the interpretation of research on the subject of research.

Methods of data collection is the most strategic step in the study, because the main goal of the research is to get data that the validity level can be justified it is necessary sources and methods of data collection are credible. According to Yin (2013), there are several methods of data collection that can be done for the case study method. First, documentation, this type of information uses different forms and should be the object of explicit data collection plans. Second, archive recordings, in many case studies, archival recording is often in the form of computerization and is a relevant evidence. This evidence includes: Recording Service, Organizational Record, Map and geographic characteristics chart of a place, list of names, Survey Data and personal recordings.

Third, interview, within this research interview holds important role. In this study, the interview plays an important role. In this research interview method used is an open standard interview namely a structured interview. Interviews were conducted individually with duration between thirty 
minutes to two hours. Most of the interviews were recorded using a digital recorder. Questions asked relating to the implementation of accrual accounting and its role in transparency and accountability. Fourth, observation, during the visits to the case study sites, researchers created an opportunity for direct observation. These observations may extend from the formal data collection activities until the causal.

\section{Informant and Information Collection}

Individuals who become informants in this study consisted of three people from Accounting who have position as Head of Division, Head of Sie and staff. Two of the SKPD have position as Head of Sub Division of Finance and staff. The following list the participants who used as informants in the study, is presented in Table 1.

Table 1 List of The Participants Who Used as Informants

\begin{tabular}{ccc}
\hline Informant Identity & Working Unit & Position \\
\hline EN & PPKD & Head of Accounting \\
MH & PPKD & Head of Sie Reporting \\
DN & PPKD & Reporting Staff \\
NN & SKPD & Head of Finance \\
AS & SKPD & Finance Staff \\
\hline
\end{tabular}

Selection of informants based on the criteria defined by Bungin (2005), such as informant is an individual that has a long and intensive blend with the activity or field of activity which is the target of research.

\section{Technical Analysis}

After obtaining the necessary data, a technique to analyze the data is needed. According to Bogdam and Biklem in Moleong (2005), data analysis within qualitative research is efforts made to work with the data, organize data, and sort the data to be a unit that can be managed, synthesized, seek and found the patterns, found what is important and what is learned and decided what can be told to others.

Analysis is done by describing research data in accordance with the determined themes. Besides making the analysis, the result is translated and outlined qualitatively to obtain an overview of the situation or event that is in the field. Within this research, the steps of data analysis are performed with data triangulation method, then data organization, data reduction; category, concept, theme and pattern determination; and lastly data interpretation.

\section{RESULTS AND DISCUSSION}

Changes in accounting aspects led to the initiative of the Government of Semarang. In the 2001 mayor of Semarang want the Government Financial Statements to be presented as Private Sector Financial Statements. There were statements of financial position to facilitate the government in making decisions. To realize that on the basis of Government Regulation No. 105 of 2000 on Regional Financial Management, Government of Semarang search reference and consultation with relevant academic preparation of accrual-based government financial statements. 
Here's a summary of the history of the process of implementation of accrual based accounting in Semarang city government during 2005 to 2009. In that period of time, Government of Semarang noted some important things. First, publishing PP 24 of 2005 concerning the use of SAP Toward Cash Accrual (CTA). Second, conceptual Framework paragraph 25, in addition to the basic financial statements (LRA, Balance Sheet, and CaLK LAK) reporting entities allowed to present a statement of financial performance and statement of changes in equity.

Third, the Government continues to apply accrual basis although SAP uses the base CTA. In addition to the basic financial statements, the Government of Semarang added Statements of Operations (LO) as Financial Performance Report. Fourth, each examination often occurs because of differences in the perception of differences in the use of bases of accounting. Fifth, in 2009, the Balance Sheet of Semarang that was served singly equity was split according to the SAP PP 24 of 2005 into EDL (Equity Fund Current), EDC (Equity Reserve Fund) and EDI or Equity Investment Fund.

In 2010, Government Regulation No. 71 of 2010 on Accrual-based SAP was issued. The publication of PP was made Semarang as the first city to implement accrual accounting. From 2010 until now, Semarang government consistently use the accrual basis in accordance with Regulation No. 71 in 2010. The process of implementation of accrual accounting in Semarang City Government begins with the preparation of the four main components to support the successful implementation of accrual based accounting. Four keys of successful implementation are as follows:

\section{Leader Commitment}

Semarang City Government as described previously had the initiative to present financial statements as private sector. This initiative raised in 2001 by Sukawi Sutarip, the mayor during that time. This initiative was presented to the field of accounting in order to be realized. The instructions received in accounting seek to conduct consultations with various parties. Consultation is done mainly by academics, practitioners, BPKP and BPK.

Accounting plays an important role in providing economic information used as a basis for decision-making or evaluation of the performance of an entity's achievement. Local Government which has culture as a public sector organization would have to have an accounting system that has a role as a basis for decision making and as an accountability evaluation. This step is confirmed by the head of the accounting field as early initiative in the implementation of accrual accounting. Such as those described in the interview process as follows:

"Accrual accounting in Semarang was initiated by the desire of the mayor at that time who wanted a generated financial report that should resemble the private sector financial reports that can be used as a basis for a decision".

\section{Drafting Regulation}

Regulation becomes legal protection and guidance for implementers to be able to apply changes to the accounting system properly. The Head of Sub Division of Finance DPKAD states that:

\footnotetext{
"The implementation of accrual accounting in Semarang City Government is never be separated from regulation drafted by the Accounting section DPKAD. This Regulation is socialized to each SKPD to be applied in preparing the financial statements ".
}

The regulation serves as guidelines for implementers to be able to run the new system. The regulation is very important for the Government of Semarang since the introduction of implementation in 2002. During that year, there has been no official regulation of the central government regarding the 
use of accrual accounting. Semarang government made various efforts in the implementation of accrual accounting; one of them is consulting with academics, BPKP and BPK. This effort is then realized by preparing regulations for the implementation of accrual accounting.

\section{Information System Development}

Semarang government accounting system was initially not integrated among the accounting entity and the reporting entity. However, in the course of implementation of accrual accounting system that is improved by hiring the services of system developers. Accounting systems and procedures become one means that become advocates for the successful implementation of accrual accounting in Semarang Government. The decision to use accrual accounting gives consequence for government's commitment to provide an integrated accounting system with information technology. The initial process is prepared to make adjustments in information technology with accrual-based accounting system. This conforms to the commitments submitted by the Mayor of Semarang that:

"From the IT side we did upgrading to fit with the existing system. It takes time and considerable expense. But because of all the attention we devote to change this system, Alhamdulillah today everything is going well ".

\section{Human Resource Development}

Semarang City Government in the preparation of implementation accrual accounting focuses on the readiness of human resources. The built accounting system would be meaningless if the human resources are not able to run the system properly. Therefore the Government of Semarang build two sections of human resources prepared for the implementation process, namely HR for Concept Development and Regulation and HR for Implementation and operator.

HR is a key to successful implementation of accrual accounting. As it has been confirmed by the head of the accounting department, within the process of HR development, some obstacles will be encountered. These constraints include not all financial staff in SKPD and DPKAD have the scientific background of accounting thus necessary intensive training is needed. The following statement from the Head of Accounting related to the development of human resources for implementation accrual accounting:

\footnotetext{
"The implementation of accrual accounting requires human resources that understand the accounting. However, not all existing staff have a good accounting capabilities. This has become one of the obstacles to implementation. Therefore to resolve the issue held intensive training for all finance staff".
}

\section{Strategic Role of Accrual Based Accounting}

The application of accrual-based SAP is one of the government's policy to improve the quality of financial management. Changes in the accounting basis from cash basis into the accrual basis is expected to generate more comprehensive information (complete) for all users (stakeholders). With the financial information presented by the government completely will satisfy the public's right to have information about the management of its resources.

The impact of the implementation of SAP in enhancing transparency and accountability can be described in a statement as follows: Application of PSAP No. 05 on Inventories Accounting for DPKAD of Semarang, in this case the ATK inventory, PSAP Number 05 regarding inventory accounting describes about government inventories accounting which includes the definition, recognition, measurement and disclosure. PSAP Number 05 describes about materials, goods and 
supplies classified into inventory, and how to recognize and measure the inventory, as well as what should be disclosed in the financial statements.

PSAP Number 05 sets on how the disclosure of inventory in any financial statements present namely: (1) the accounting policies used in measuring inventories; (2) a further explanation regarding supplies such as goods or equipment used in public services, goods or equipment used in the production process, the stored goods which are to be sold or handed over to the public; and (3) the condition of inventories. Affirmation of the benefits of implementing PSAP Number 05 delivered by the staff of the DPKAD accounting department that:

"If the PSAP Number 05 is implemented correctly, the real conditions in CaLK will be shown. The recognition and measurement of inventories were carried out properly in accordance with $S A P$, and the condition of the end of the budget period carried out a physical check of inventory to determine the real number and the physical condition of the inventory and to know how much inventory have actually been used to be reported on the operational reports ".

One of the goals of the accounting standards is to improve government accountability through the existence of a reliable financial reporting. This is due to the accounting standard set of systems, procedures and implementation of accounting policies in general, and with the standards that the report presented by the entity will be more easily audited and compared well with the same organizational unit or with the prior year period. The existence of accounting policy will maintain the consistency of each financial statement items presented. Based on the interview with the DPKAD Head of Accounting Semarang Government showed that:

"Increased accountability of local government financial statements in applying the accrualbased SAP includes the financial statements which are presented more comprehensive, truthful and objective; increase in security will be the region's assets. The implementation of accrualbased SAP can assess the financial performance of local governments in accordance with the principles of economical, efficient and effective ".

Table 2 is a summary of the strategic role of the implementation of accrual based accounting towards the transparency and accountability of financial statements:

Table 2 Strategic Role of Accrual Based Accounting Implementation

\begin{tabular}{|c|c|c|}
\hline No. & Before Implementation & After Implementation \\
\hline 1. & $\begin{array}{l}\text { On a cash basis, transactions and events are recognized or } \\
\text { recorded when there is cash revenue and expenditure } \\
\text { account. At the end of the year, if any expenditure debts is } \\
\text { known, then journalizing will not be carried out for the } \\
\text { transaction. LRA will not present the expenditure of debt } \\
\text { (principal or non-principal) because there is no cash } \\
\text { outlay happens. Thus the report user will not know that } \\
\text { there is a debt obligation of the government expenditure } \\
\text { that should be budgeted in the next fiscal year because the } \\
\text { balance sheet is also not an obligation for the government } \\
\text { to be reported. }\end{array}$ & $\begin{array}{l}\text { The advantages of the accrual basis is that the debt } \\
\text { burden as well as the expenditure debt can be } \\
\text { known at the same time where the transactions } \\
\text { and promising transparency for all transactions } \\
\text { occur during the reporting period compared to the } \\
\text { other two basis, cash basis and cash basis towards } \\
\text { the accrual. }\end{array}$ \\
\hline 2. & $\begin{array}{l}\text { Cash accounting can not provide information relating to } \\
\text { the entire cost of providing public services. }\end{array}$ & $\begin{array}{l}\text { Provides financial information that can be used to } \\
\text { calculate the entire cost of the service based on on } \\
\text { the cost of all the used resources (including non- } \\
\text { cash resources such as the use of fixed assets). By } \\
\text { using the full cost method, efficiency analysis and } \\
\text { the estimated need for funds can be performed to } \\
\text { replace assets that are being used. }\end{array}$ \\
\hline
\end{tabular}


Table 2 Strategic Role of Accrual Based Accounting Implementation (continued)

\begin{tabular}{|c|c|c|}
\hline No. & Before Implementation & After Implementation \\
\hline 3. & $\begin{array}{l}\text { Financial management accountability is limited to the } \\
\text { resources of cash in and cash out. }\end{array}$ & $\begin{array}{l}\text { Accountability is getting better as it extends to } \\
\text { assets other than cash and liabilities. With accrual } \\
\text { based accounting, an entity needs to clearly define } \\
\text { the service performance to be achieved and the } \\
\text { overall cost of implementing such services. }\end{array}$ \\
\hline 4. & The absence of operational reports & $\begin{array}{l}\text { Provide government operational information that } \\
\text { have the potential to increase transparency and } \\
\text { improve fiscal responsibility. }\end{array}$ \\
\hline 5. & $\begin{array}{l}\text { Prior to the implementation, there is no classification of } \\
\text { cash flows into group activities. }\end{array}$ & $\begin{array}{l}\text { Classification of cash flows into groups operating } \\
\text { activities, investing activities and financing } \\
\text { activities, will provide information that can be } \\
\text { used to trace the influence of government cash } \\
\text { flows related to economic activity. }\end{array}$ \\
\hline
\end{tabular}

Source: Adapted from primary data (interview)

\section{CONCLUSION}

Conclusions based on the results and discussion shows there are four main components to support the successful implementation of accrual accounting namely management commitment, regulation preparation, information systems development and human resources development. Afterwards the perpetrators believe that the implementation accrual accounting can improve transparency and accountability in financial report can be presented more comprehensive, truthful and objective. The study also shows that the adoption of the new system in an entity is not easy. Lengthy process must be taken to change the existing system by making changes in some aspects. The concept of IPM used by Dambrin, Lambert, and Sponem (2007) before used by Harun, Peursem, and Eggleton (2012) analyze the institutionalization process of accrual accounting in Indonesia is relevant enough to explain the process of implementation of accrual based accounting in Semarang Government. This study is limited to the analysis in a Local Government, so the ability of researchers to explain part of the process of implementation of accrual accounting is still limited. Future research could conduct a study on other Local Government to expand the research.

\section{REFERENCES}

Baboojee, B. (2011). Improving service delivery through changing from cash to accrual accounting: Lessons for South Africa based on a cross-national study. Research report presented in partial fulfillment of the requirements for the degree of Master of Development Finance. University of Stellenbosch, Stellenbosch, South Africa.

Bungin, B. (2005). Analisis Data Penelitian Kualitatif Edisi 1. Jakarta: Raja Grafindo Persada.

Chariri, A. (2006). The Dynamics of Financial Reporting Practise in an Indonesian Insurance Company: a Reflection of Javanese Views of an Ethical Social Relationship. Disertasi, School of Accounting and Finance, University of Wollongong, New South Wales, Australia.

Dambrin, C., Lambert, C. \& Sponem, S. (2007), "Control and change-analysis of the process and institutionalization”, Management Accounting Research, 18, pp. 172-208. 
Harun, H., Peursem, K. V., \& Eggleton, I. (2012). Institutionalization of accrual accounting in the Indonesian public sector. Journal of Accounting and Organizational Change, 8(3), pp. 257285.

Khan, A., Mayes, S. (2009). Transition to Accrual Accounting, Retrieved on July 20, 2015 from http://http://blog-pfm.imf.org/files/fad-technical-manual-2.pdf

Moleong, J. L, (2005). Metodelogi penelitian Kualitatif. Bandung: PT Remaja Rosda Karya.

Peraturan Menteri Dalam Negeri Nomor 64 Tahun 2013 tentang Penerapan Standar Akuntansi Pemerintahan Berbasis Akrual pada Pemerintah Daerah.

Peraturan Pemerintah Nomor 71 Tahun 2010 tentang Standar Akuntansi Pemerintahan.

Rkein, A. (2008). Accrual Accounting and Public Sector Reform: Northern Territory Experience. A thesis submitted in fulfilment of the requirements for the degree Of Doctor of Philosophy, School of Law and Business Faculty of Law, Business and Arts Charles Darwin University.

Setyaningsih, T. (September 2013). Studi Eksplorasi Pemahaman Aparatur Pemerintah Daerah dan Anggota Dewan Terhadap Standar Akuntansi Berbasis Akrual. Simposium Nasional Akuntansi XVI, Manado, Indonesia.

Tarigan, E.P.A. (2012). Standar Akuntansi Pemerintahan Dalam Mewujudkan Akuntabilitas Dan Transparansi Pengelolaan Keuangan Daerah. Tesis Pascasarjana UGM, Yogyakarta, Indonesia.

Yin, R.K. (2013). Studi Kasus: Desain dan Metode. Jakarta: Raja Grafindo Persada. 